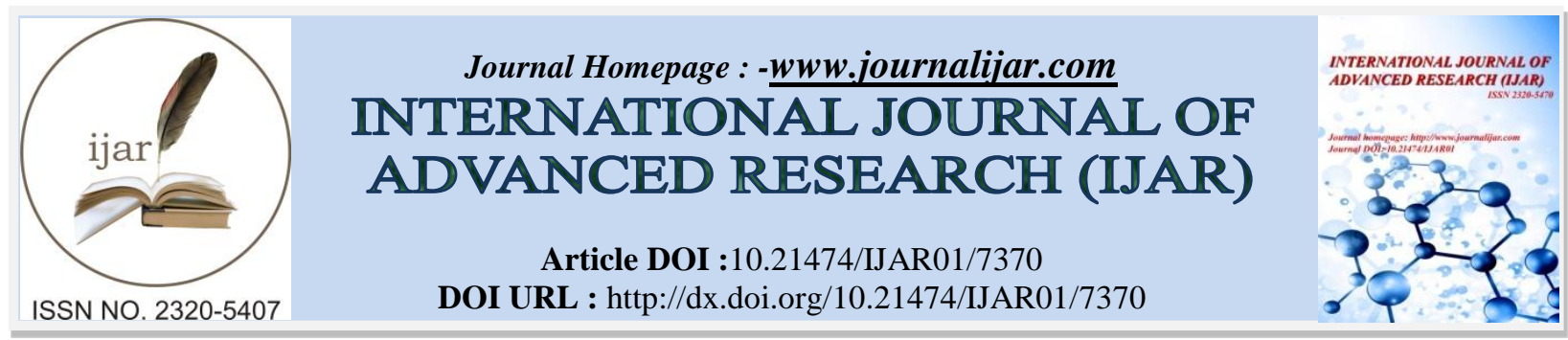

RESEARCH ARTICLE

\title{
THE EFFECTS OF NATURAL ENVIRONMENTAL DATA IN THE TRADITIONAL JAPANESE HOUSE DESIGN.
}

Gözde Çakır Kıasıf.

Halic University, Faculty of Architecture- Department of Architecture, Sütlüce-İstanbul / TURKEY.

\section{Manuscript Info}

Manuscript History

Received: 08 May 2018

Final Accepted: 10 June 2018

Published: July 2018

Keywords: -

Traditional Japanese House, Natural Environmental Data, Architectural Design.

\begin{abstract}
Formed by group of islands, the natural physical structure that Japan plays a big role in its vernacular architecture. Because natural environment is an important matter that shapes architecture, wants to be in harmony with structures and integrates with human needs. The characteristics of the nature play a major role in shaping the developing civilizations there. In this context, the fact that Japan has monsoon climate is geologically located on the earthquake zone and has a sloping topography, which are the most striking features in the formation of architecture. Built with local natural wood, reed and bamboo-like materials Traditional Japanese house are structures with raised floor, on raised legs, has a design concept that integrates with nature, not defying nature with its physical environment. In the formation of the skeletal system minding that structures have a limited lifetime, instead of nails, dove-tail joints are preferred that conduces flexible designs. In the traditional Japanese house where the minimal sense of space is embraced, the construction techniques and interior designs are more carefully considered due to the earthquakes. Thus, the structure and the physical surroundings are confronted as parts of an organic whole complementing to each other. The purpose of this study is to show how natural environmental data plays an important role in shaping the traditional Japanese house. Instead of resting with nature, listening to it and being in communication shows that there will be more positive and lively outcomes for the users.
\end{abstract}

Copy Right, IJAR, 2018, Arll rights reserved.

\section{Introduction:-}

In the formation of a particular place, the physical environment is one of the most important factors in the architectural style of that area. In addition to physical environment data, the building sector, which also benefits from science, art, culture and technology, seeks to respond to the expectations of future generations, taking into account the lifestyles of users. Climate, vegetation, topographic structure and geological features as factors that shape the natural structure of a region, give serious clues about the traditional architecture of that region.

\section{Purpose of the study: -}

In this study, it is aimed to show that the natural structure of Japan and the physical environment data are serious factors in the formation of the traditional residential architecture. The strengths and weaknesses of the region's natural structure and what kind of opportunities and threats it forms in the traditional architecture of the region will 
be investigated.

Scope and method of the study:-

First of all, the natural structure of Japan will be studied. After mentioning the topographic and geological features of the country, information about climate and vegetation will be given. Later on, the architectural characteristics of traditional Japanese houses will be mentioned as in building material, structural system, construction techniques and interior space organization. Finally, a general evaluation will be made by focusing on the role of the country's natural data in shaping the traditional Japanese house. As a method, a search of the literature has been done. Magazine articles, books, technical reports and conference notices with significant area indexes related to the traditional Japanese House and Japan's natural structure have been thoroughly examined. After scanning a coherent and deep secondary source, the information that was seized was conducted with critical evaluation.

\section{Natural Structure of Japan:-}

Japan, a community of islanders, is located east of the Asian continent, between $123^{\circ}$ and $149^{\circ}$ longitudes and $26^{\circ}$ $46^{\circ}$ north latitudes. The total area is $377.815 \mathrm{~km} 2$. Japan, which has an arc view on the map, has 4 large team islands besides hundreds of small island structures. These are named as Honshu, Hokkaido, Kyushu and Shikoku island chains in order of their sizes (Figure 1). This mountainous country, only 10\% is settled by people. (Pinto et al., 1997).

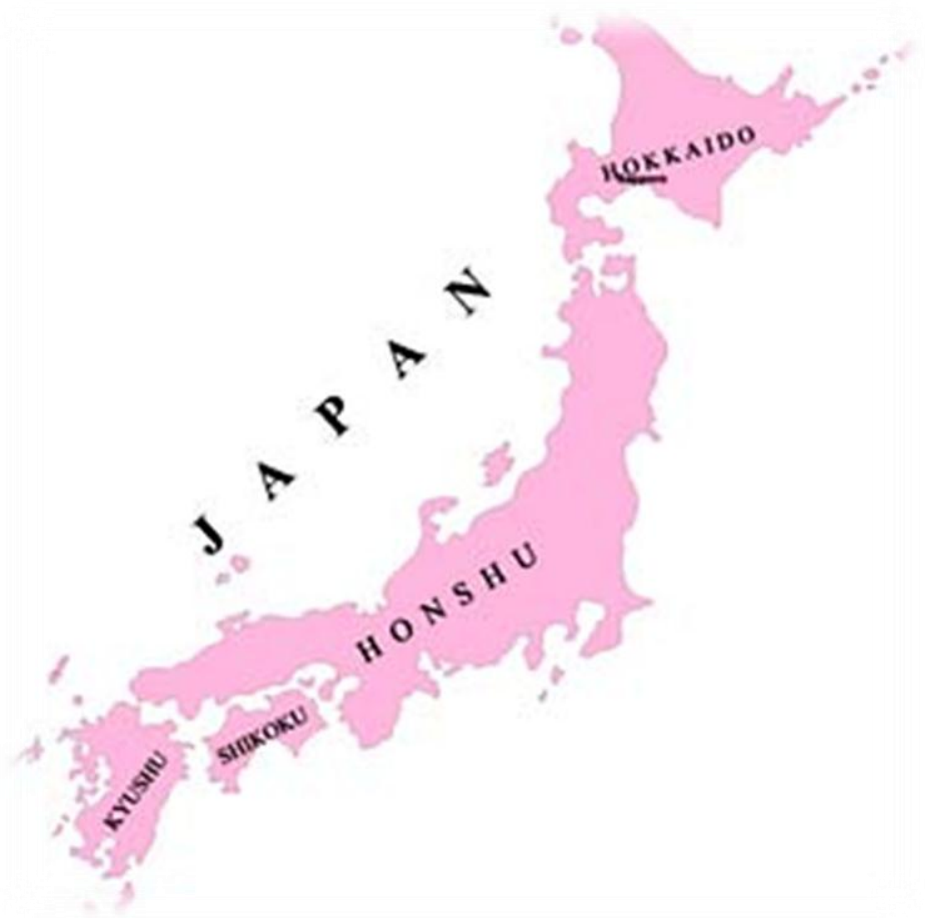

Figure 1:-Four Great Japanese Team Island (URL-1)

\section{Topographic Structure:-}

The four thirds of Japan, which an island nation, has more than 15\% of slop. Japanese islands actually form part of mountain ranges extending from Southeast Asia to Alaska. The shores are long and rocky. Nearly 70 percent of Japan's total surface area is mountainous. The terrain is generally not suitable for housing. The mountains are filled with clear lakes, rivers and numerous valleys. It is a country that is rich in rivers. In addition, there are plenty of crater lakes (Figure-2). The name of the largest is Lake Biwa, and it is located in the north-east of Kyoto. The vegetation comes from the lush forests. There are many fault lines and geological depressions in Japan. Because of this feature, there are many earthquakes and volcanic activity. There are still 60 active and 165 extinct volcanoes in the country. Fuji, the highest mountain in the country, is 3776 meters tall and is one of the active volcanoes. One of the popular recreation and tourism focal points, hot water springs are products of these volcanic formations (URL2). 


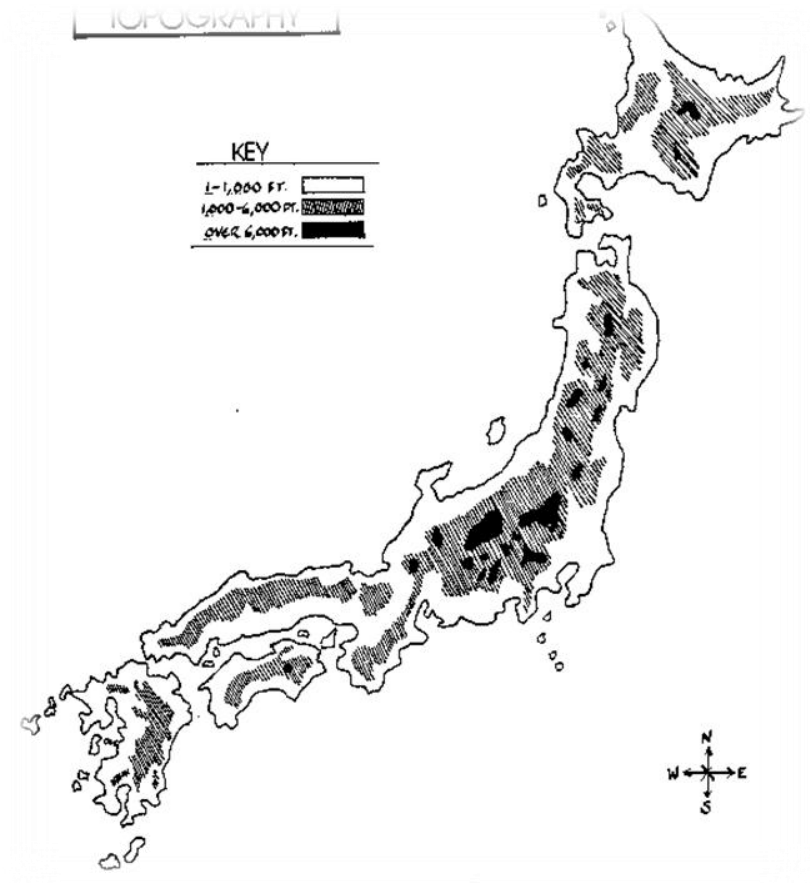

Figure-2:-Topographic Structure of Japan (URL-11)

\section{Geological Structure:-}

Since the Paleozoic era, frequent ground movements have taken place in the Japanese islands that lie adjacent to the east of the Asian continent. The effects of ongoing volcanic activity have also been observed since the Cenozoic era. For this reason, the topographical structure of the islands shows great changes. Due to the fossa-magna line extending to the north and south from the center of the Honshu Island, the islands are divided into two as northeast and southwest. In Northeast Japan volcanic rocks belonging to the Cenozoic era are spread in large areas. In some small islands, rocks belonging to the Paleozoic and Mesozoic era are encountered. Southwest Japan is divided into two zones along the middle tectonic line, the Japanese sea coast and the Pacific Ocean. In the Pacific zone, Paleozoic and Mesozoic finds and metamorphic rocks are spread along the middle tectonic line. Their effects are also reflected in mountainous areas. (Yüksek, 2002)

\section{Climate:-}

The large islands that make up Japan have variable climatic conditions. The reason for this is the presence of the islands community in important climate transition regions and the impact of the Pacific Ocean.

In the north of the country, horizontal climate and in the south boreal and sub-tropical climatic characteristics are observed. Due to its location in the east of Asia, monsoon climate is dominated by two kinds of influences. The monsoon winds blowing to the north take cool winds to Japan's Hokkaido island, while the southern monsoons carry hot winds to the country. For this reason, in the north the winters are cold and snowy, and the summers are dry and hot. In Central and Southern Japan, summers are hot and rainy, winters are mild and abundant. Winter is sunny and soft on the Pacific coast. On the shores of the Japanese sea there is a cloudy weather.

The mountainous interior is one of the snowiest parts of the world. Because of the cold-water currents of Oyasivo and cold weather masses from the inner parts of Asia the winter in northern islands are cold and long. The most distinctive feature of Hokkaido is the hard winters. In September, there are severe winds, typhoons and torrential rainfall in the inner parts of the country. The capital is at the same latitude as Tokyo, Tehran, Los Angeles and Athens. In contrast to the humid and very hot air seen in summer months, it is temperate with low humidity and snowfall in winter (Saraçoğulları, 2006). The highest precipitation is observed in the western part of Honshu Island and Shikoku and Kyushu Islands. The average annual rainfall in Japan is $1700 \mathrm{~mm}$. From north to south, the annual average temperature is above $6{ }^{\circ} \mathrm{C}$ in Hokkaido, $6-12{ }^{\circ} \mathrm{C}$ in northeast Honshu, $12-22{ }^{\circ} \mathrm{C}$ in southern Honshu, $22{ }^{\circ} \mathrm{C}$ in Shikoku and Kyushu islands (Figure-3) (Yüksel et al., 1997). 


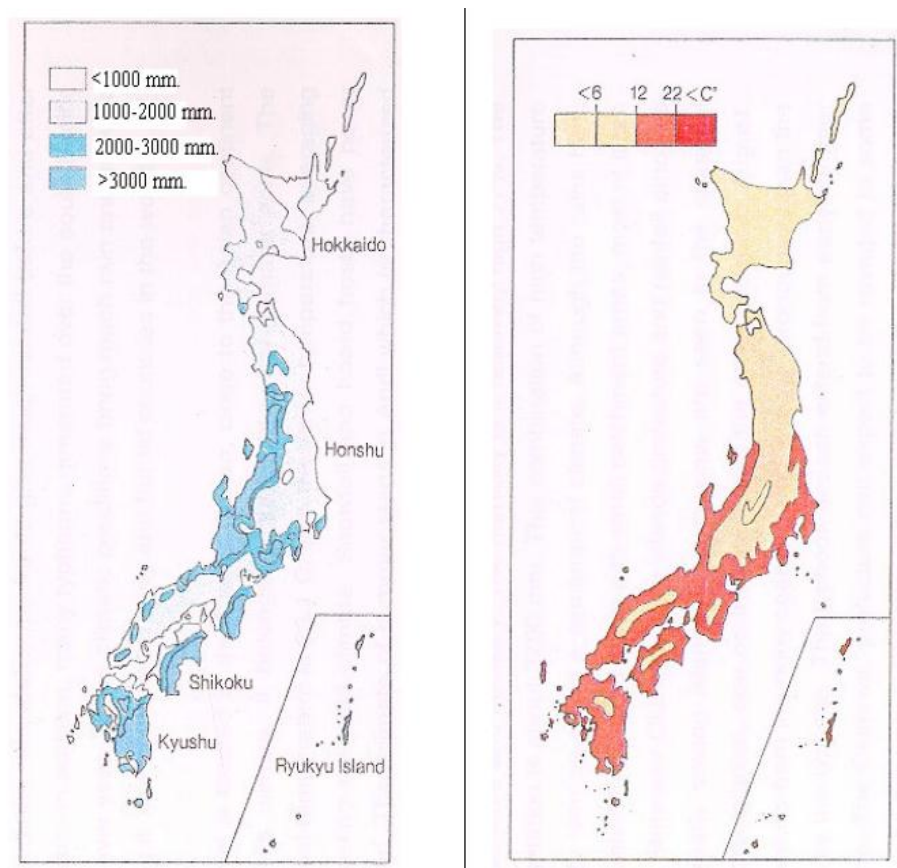

Figure-3:-Japan's Annual Average Precipitation and Temperature Values (Yüksel et al., 1997)

\section{Vegetation:-}

Japan's natural vegetation are formed by lush forests that cover $70 \%$ of the land. The subtropical forests that occur in oak, hairs and bamboo trees are located in the south. In the northern part, there are forests that come from large leafy trees such as birch, beech, oak, poplar, and maple. The most popular tree species in Japan, except for Hokkaido tree, is Sugi which is also called Japanese Cedar. The Japanese Selvish, also called Hinoki, and the Japanese Red-headed Crane called Akamutsu are among the most popular tree species after Sugi (URL-2).

In Japan, the cherry flowers, which are called "sakura", blossoms in March which symbolizes the arrival of spring. Throughout the month of April, especially in the Kyushu region, cherry trees provide spectacular scenery. Then comes the period of hanami (flower exhibitions) and thousands of people attend the festivals and watch the flowers displayed with interest (Figure 4). The Hanami tradition has been one of the most important proofs of how Japanese are intertwined with nature since the Heian period (794 1185). The magnificent images of grown flowers in a short period of time remind people of how mortal world life is. (URL-3)
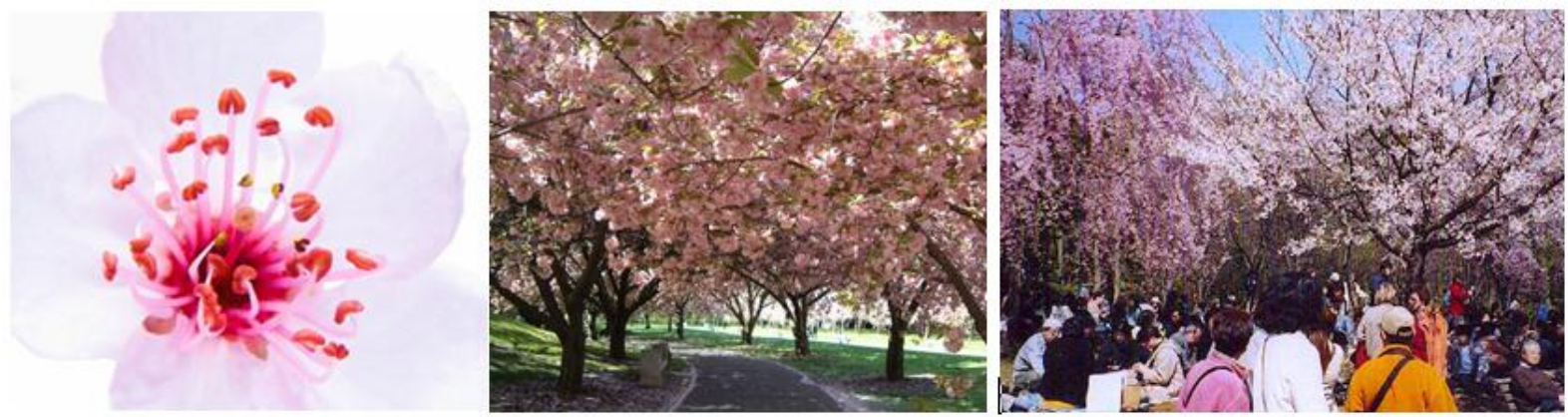

Figure 4:-Sakura Flowers and Hanami Festivals (URL-4)

The period from the beginning of June to the middle of July is very rainy in Japan and is called "Tsuyu Rainfall Season". The intense Tsuyu rains are hot and humid, and they give the first signs of summer. In summer, the air temperature rises above 30 degrees and the intense humidity makes the air unbearable. At weekends, people either go to mountains that are affected by high and low temperatures to cool off, or they try to cool off on the beaches. The weather is gradually cooling down during October and November, and suddenly everywhere is covered with 
red, brown, yellow, and green colors. Koyo (red leaves) provide spectacular scenery especially at the skirts of Mount Fuji and in temples in Kyoto.

\section{Traditional Japan Housing Its Architecture and Characteristics:-}

As in all the fields of art in Japan, the principle of simplicity is adopted in architecture, in the materials, technology and design the most nature-based and basic ones are preferred. Especially considering the traditional Japanese way of life and architecture, it is possible to see the concept of "less is more" which is an important concept of modern architecture (Şentürer, 2000).

The most important concept that comes to mind in Japanese architecture is the concept of temporaries, which comes from its beliefs. The Japanese are approaching everything temporarily.

The reason for this is due to the rapid social changes in Japan, and therefore the changeable plans conduce better results than others. Another concept is the holon concept, which is a basic design approach and aesthetic principle pursued in Japanese architecture. One of the most important principles of Japanese architecture is the "part-whole" relation. And this is explained by the concept of holon. This concept includes parts that have qualities that give information about the whole, such as a gene, a tree, etc. (URL-5). As can be understood from this, Japanese architecture has many commonalities with organisms in the environment.

Being a part of nature is seen as a greatness that the Japanese give themselves. In nature, building a building that integrates with nature without defying nature is one of the best examples in Japanese philosophy of the idea of taking part in nature (Ayverdi, 1972).

\section{Building materials:-}

The building materials they prefer in traditional Japanese architecture are due to the ecological, natural and natural materials that always exist in nature with the influence of social belief systems. Japan, which is abundantly rainy and moist, is quite a timberland. The total forest area in the country is approximately 23.85 million hectares. $67 \%$ of the total land is covered with forests. 56.68\% (13.52 million hectares) of forests are natural, $43.32 \%$ (10.33 million hectares) are plantation forests. Wood is a traditional building material and timber of sufficient quality for buildings can be obtained (Yüksek, 2002).

Each part of the trees is evaluated for the formation of a structure, including doors and windows, as coating material and also for decorative purposes.

The quality of the trees varies depending on the season. Trees are classified according to their quality. Painting on wood materials is not preferred, it is left in its natural state and only protective polish is applied on it. Designers who use different textures of different trees turn the space into a work of art.

Timber mainly used in the skeleton system of houses;

1. Hinoki Timber (Chamaecyparis Obtusa)

2. Hiba Timber (Thujjopsis Dellabrata Sieb)

3. Tusuga Timber (Tusuga Ssieboldii)

4. Sugi Timber (Cryptomeria Japonica)

5. Pine Timber - Matsu Pine, Black Pine and Kuro Matsu Pine (Saraçoğulları, 2006).

Timber used for decorative purpose in traditional Japanese house are;

1. Keyaki Timber (Abelicea Seratta)

2. Kiri or Paulownia Timber (Paulownia Tomentosa, Bail)

3. Momjiji Timber or Kaede Timber (Acer Palmatus)

4. Kuwa Timber (Morus Alba)

5. Indian and Indo-Chinese Timber

6. Byakudan (Sandalwood) - Shitan (Red Sandal)

7. Echinacea Tree Tagayasan (Caesalpinia Ferrea) (Saraçoğulları, 2006).

Also, among the structural wood materials, bamboo is often a preferred material. Bamboo are used in roof rafters, massive surfaces, plant cages and fences (Figure-5). The bamboo material gives the building a pleasant and soothing atmosphere and a rustic atmosphere. But it is not as strong and durable as wood. There are many kinds of bamboo in 
Japan. Madake (Phyllostachys Puberula), Mosochiku (Phyllostachys Mitis) and Hachiku (Phyllostachys Puburula) are the most frequently used bamboo species in residential structures. The bodies of bamboo trees are about $10-20 \mathrm{~m}$ tall. (URL-6).
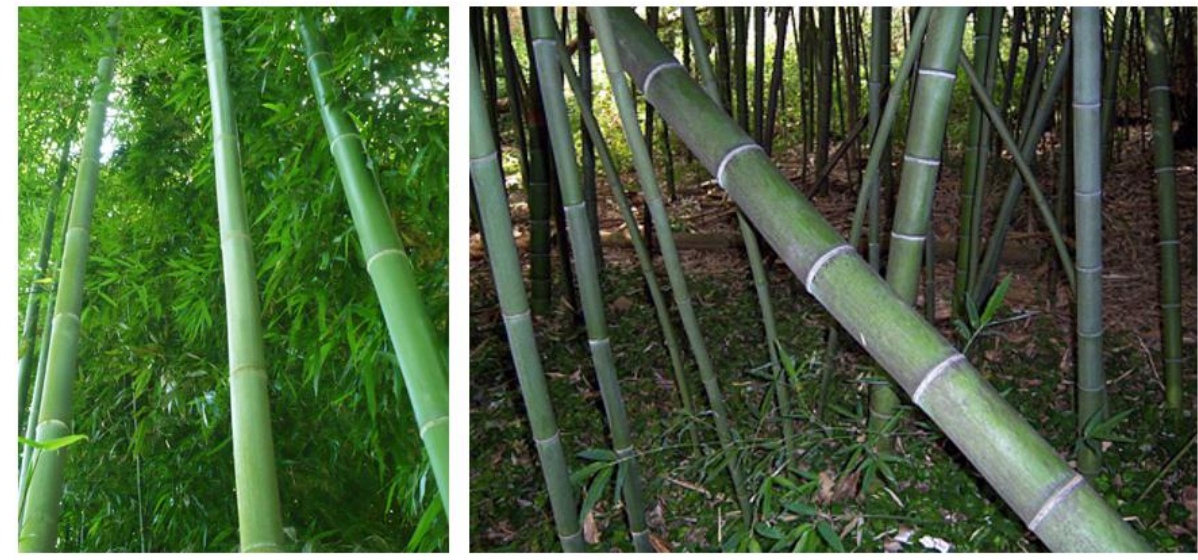

Figure 5:-Bamboo Trees (URL-7)

Indoors, besides wood, there are also tatami straw, produced from rice hay, paper (washi) for sliding doors, materials like reed are used. Boards, doors and windows are made from paper pasted on very thin light wood slats. The semi-transparent compartments and doors separating spaces are on floors of tatami mats and the weight of the standard door does not exceed several kilos (Güvenç, 2010).

\section{Structural Systems and Construction Techniques:-}

Japanese houses' skeletal have frame system. The Japanese have combined art with wood to create high-value buildings that are respected in traditional housing design. German architect Bruno Taut likens Japanese carpentry art to Greek stone and marble carving art. Each corner of the space and structures is processed in such a way that it will form a work of art in the direction of the material and carpenters are being cultivated with their own techniques. Despite the excellence in carpentry art, the building techniques are quite simple. The skeletal system consists of only vertical and horizontal connections. The Japanese have succeeded in developing very successful designs in durable wooden structures by improving their building techniques through the history.

In their traditional construction technique (Figure 6), wooden columns are erected at intervals of about $1.8 \mathrm{~m}$ on stone foundation. The ground floor level is $50-80 \mathrm{~cm}$ high from ground level. There are no fillings under this elevated flooring. 3 Shaku, $90 \mathrm{~cm}$ spaced short stakes, are attached to the stone foundation. Horizontal elements are laid approximately $60 \mathrm{~cm}$ wide. The vertical elements are connected at each floor level.
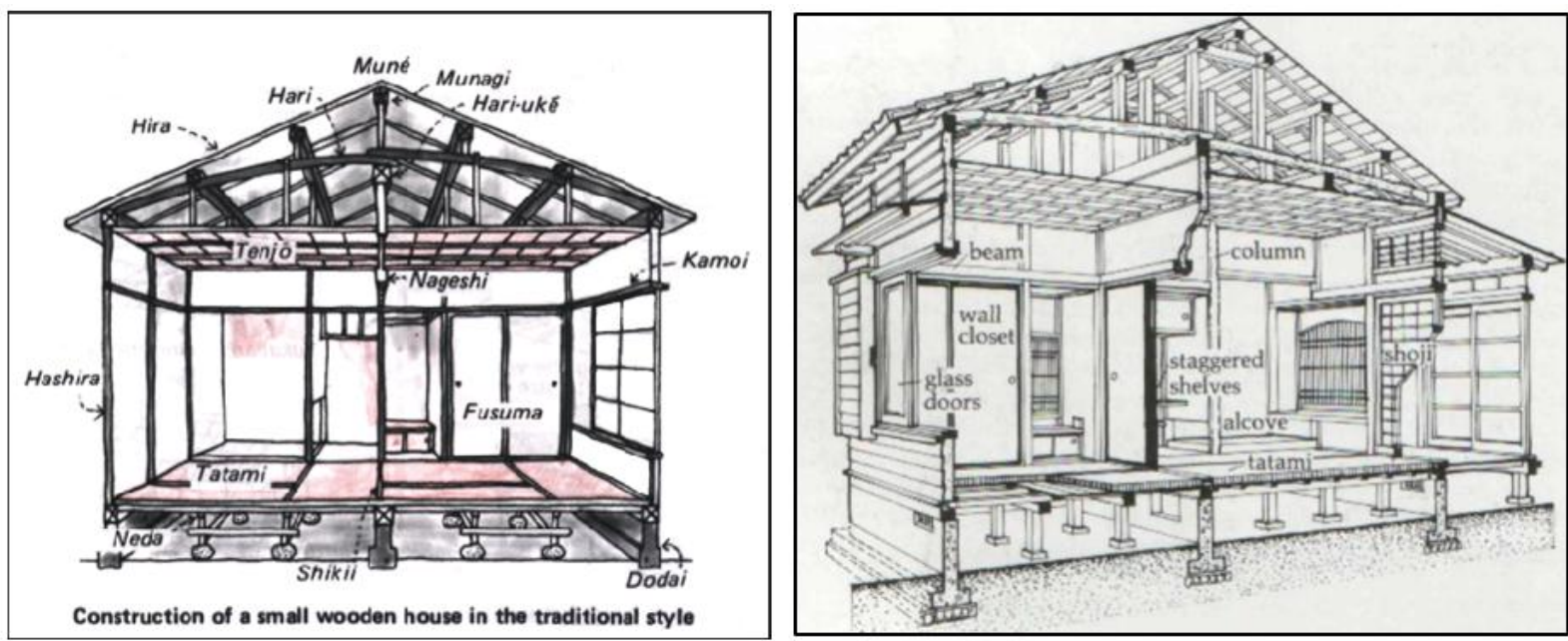

Figure-6:-Traditional Japanese House Sections (URL-8) 
Metal elements are not used to combine wood. It is combined with elegant and special fasteners using conventional methods (Figure 7).
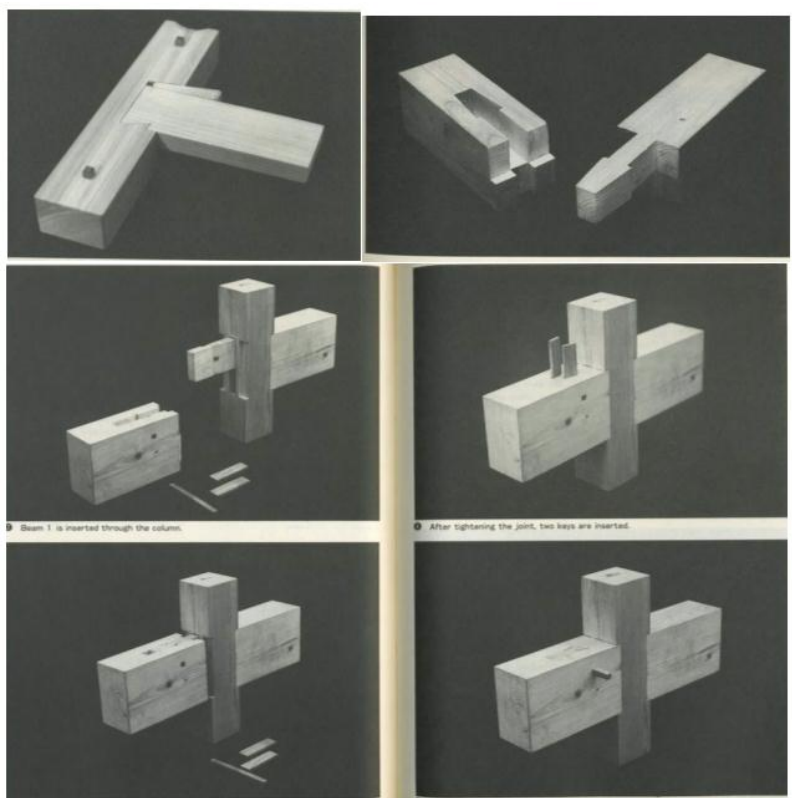

Figure 7:-Special Combining Details in Traditional Japanese Architecture (Sumiyoshi and Matsui, 1990)

The most important place to bring people closer to nature is the veranda, called "engawa", which provides the continuity between indoors and outdoors in Japanese house. In the verandas that provides fresh air and daylight to its users, the most suitable material to be used is wood. (Yagi, 1982).

The roof, which is an important element in the formation of the traditional Japanese house, that brings attention with different forms. "Irimoya", "Kirizuma", "Hogyo" and "Yosemune" roofs are examples of Japanese roof types (Figure-8.). (URL-10)
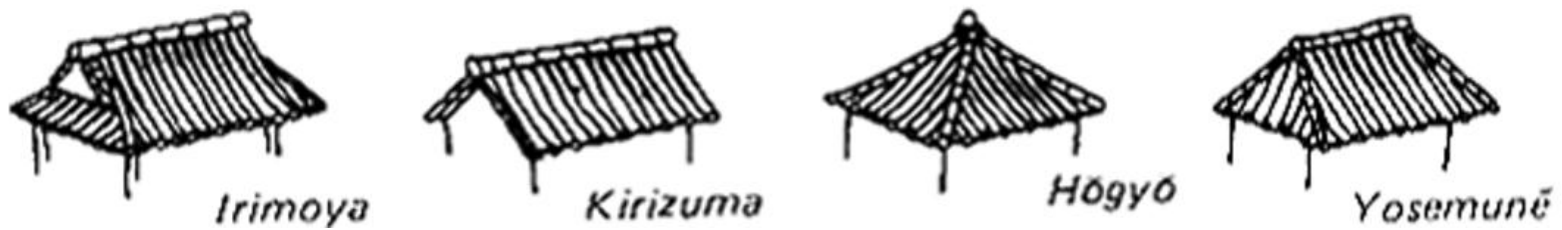

Figure-8:-Roof Types in Traditional Japanese Houses (URL-10)

The Japanese roofs are distinctive with their wide fringing distances. This opening can range from $45-90 \mathrm{~cm}$ to $75-$ $120 \mathrm{~cm}$ wide. Thus, even though the Japanese house is protected from sunlight in summer, the amount of light going in will be reduced in winter. Special joining techniques are used without any nails in the construction of the roof and fringe (Figure 9). 


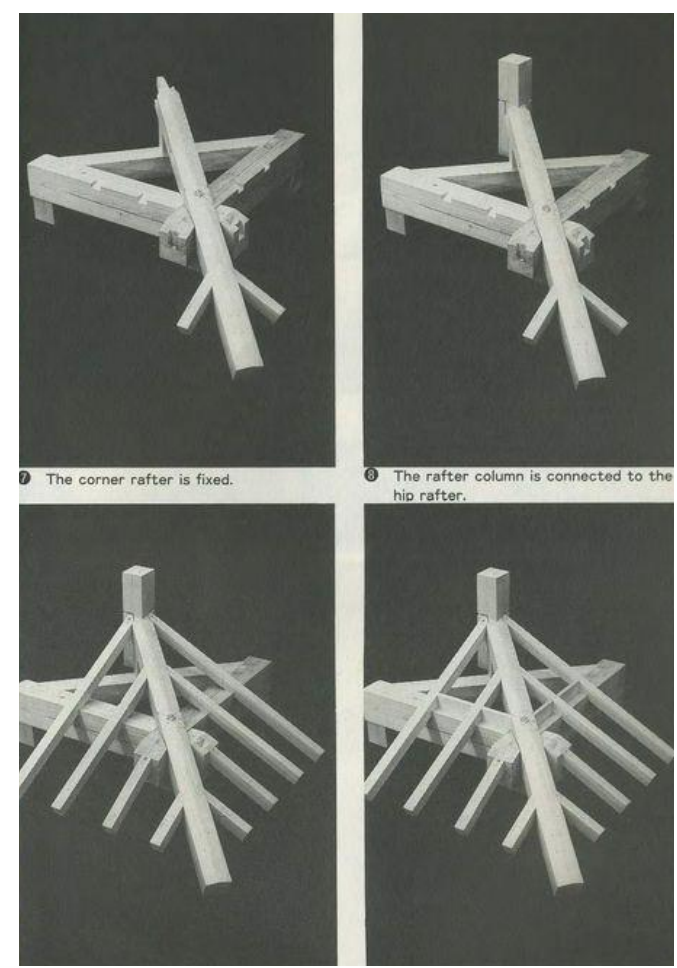

Figure 9:-Special Joining Techniques Between Roof and Fringe (Sumiyoshi and Matsui, 1990)

To protect the roof material from rain water; cane, reed, grass and straw are covered with layers formed by plant stalks. This cover is rain, snow and heat repellent; in humid weather, hot air rises upwards and is thrown out to cool the house (Güvenç, 2010). Japanese ceilings are usually carried out by connecting thin wooden beams perpendicular to the wooden panels. The beams support cornices forming and surrounding the ceiling. Generally, the spacing is $0.25 \mathrm{Ken}$ or $1.5 \mathrm{Shaku}(45.5 \mathrm{~cm})$ and they are suspended with fine lines from the upper roof beam. The size and length of ceiling timber vary depending on the size of the room. The Sugi wood comes as a ceiling covering that is frequently used. Wood and bamboo ceilings are used together as a covering material. The patios and corridors have a sloping ceiling type and have the same parallel texture as the roof (Saraçoğulları, 2006).

\section{Interior Organization:-}

The flooring is formed attached to the frame system. This surface is covered with a mat made from rice straw called "tatami". The unit is about $90 * 180 \mathrm{~cm}$ in size. All sections of the house, room dimensions, story heights are calculated on the basis of these tatami measurements. Living space (ima) in the context of interior design is the main space where the daily life of the family is maintained and is a functional space where seating, eating, working and lying activities are performed. The need for storage fulfilled with fixed cabinets that also responds to many needs in the room. Among the rooms, there are translucent sliding divider "shoji" and opaque sliding divider "fusuma" wall systems that implements flexible design understanding. The entrance to the traditional Japanese house is called the "genkan". Genkan must be kept as low as a step between tatami level and ground level. By removing the shoes in the entrance hall, the clean and dirty environment is clearly separated from each other. The traditional Japanese House has a decoration corner with a height of $5-7 \mathrm{~cm}$ from the so-called tokonoma (also known as honor or art corner) in the living room (Figure 10). This section contains various wall decorations or flowers (URL-9). 

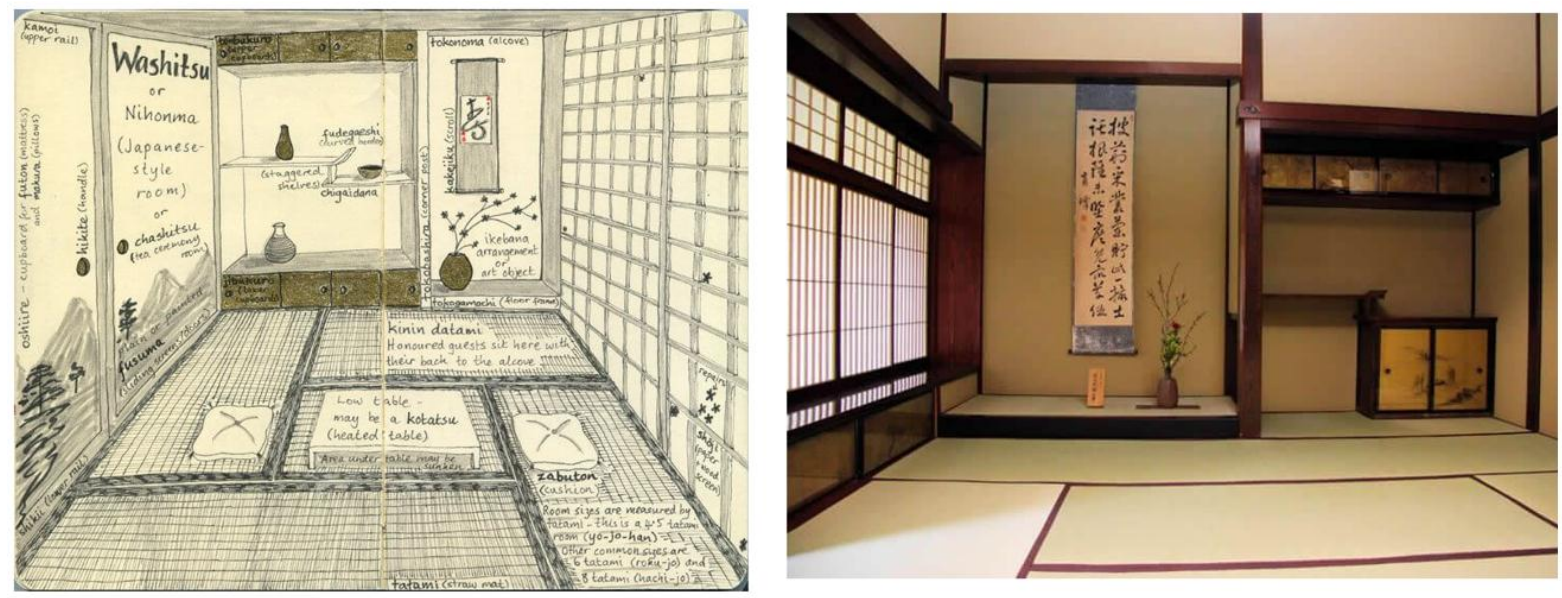

Figure 10:-Interior Design Elements in Traditional Japanese House (URL-9)

The Role of The Japanese Natural Environmental Data in The Traditional Japanese House: -

In the formation of the traditional Japanese house, the topographic and geological structure of the region, climatic characteristics and vegetation has been the important data in this study.

\section{Topographic and Geological Structure:-}

In Japan, which has a sloping and mountainous topographic structure, there are many faults and depressions. In the country where earthquakes occur frequently, this fact has been confronted and revolutionary architectural methods have been developed. In this context, since ancient times, timber skeleton structures have been preferred and great successes have been achieved in fighting with earthquakes. Timber structural components are durable, easy to assemble and insulate. Compared to the other building materials, timber, since it has many advantages as a building material against earthquakes, is seemed to be used frequently as structural systems. Because wood as a material is sturdy and light. Since there are many elements and special joining details on the timber structure frame, there are many load paths that absorb the forces and distribute the earthquake's energy.

Hearn, who is a researcher on Japanese philosophy, explains the characteristic of Japanese culture: "The Japanese are people on the move. Their house will not be built for a long time. The Japanese territory is moving. The rivers are constantly changing coasts. The ability to live with as few objects as possible, without using any kind of mobbing that hinders mobility, shows an advantage they have (Rasmussen, 1994). For this reason, in this earthquake zone area, wood is often used as a light, flexible and natural material.

\section{Climate and Vegetation:-}

Although the large islands that make up Japan have different climatic conditions, it is observed that in summer in general Japan is struggling with vigorous moisture. In this context, openings in interior and exterior spaces are due to intense moisture in climatic characteristics besides the religious beliefs which also is one of the reasons for open spaces. Bruna Taut explained this humidity factor dominating the region as follows (Ayverdi, 1972): "In a summer without any wind, especially from mid-July to mid-September, that one does not even want to see the eyes of her eyes, the only requirement being the presence of a roof over their head; and whatever their eyes are looking for, there is another "air" hole. I did not see Japan's "creativity" as the sole influence of simplicity and sophistication; Humidity is self-restraining as the cause of simplicity and space; it seems that the space covered by the blank and simple form gives a climatically cooler impression compared to the fancy and furnished. "

To mention about the effects of climate characteristics of Japan on the traditional architecture;

1. In Japanese architecture, there must be many openings in the architecture in order to combat moisture. Instead of walls, there are moving intermediate compartments. These compartments allow flexible design. When requested, the wind is taken for the house and thus the cooling effect of the wind is benefited.

2. The ground plane is raised from the ground to prevent decay and to provide good air circulation. At the same time, these altitudes prevent floods inside houses during periods of heavy rainfall.

3. The roof is extended as far as possible with a wide fringing appearance, all openings and passages are protected from rain and sun light. 
4. In front of the south-facing habitats there are verandas called engawa which provides refreshing effect. With the patio formations, an environment like a canopy is brought to the market and user comfort is taken into consideration.

5. The high sloping roof is designed due to the heavy snowfall in winter. The reason behind this roof design is to lighten the burden of the snow load on the building and allowing the snow to slide down.

Japanese, who always gives importance to nature, have most of their plant cover formed by lush forests. Due to the large number of high-quality tree species found in the region, the traditional housing architecture uses a skeleton system with a sturdy timber load-bearing system that is resistant to earthquakes. It is possible to see high quality timber building materials besides the structural system in every part of the building: in the interiors, in the roof, in the veranda and so on. Japanese architecture that admires natural vegetation and nature has shown in every sense the respect to nature with open and transparent details that integrate the interior with the garden in the traditional housing design.

\section{Conclusion:-}

The island nation of $377.815 \mathrm{~km}$ square area of Japan's three quarter is on more \%15 slope. Geologically, it is on earthquake zone. Climatic features play a major role in shaping traditional architecture in Japan, which has different climate transition regions. The use of raised flooring, upholstered feet, exposed structure, flexible design, verandahs and locally native materials is the most striking point of traditional residential architecture.

In Japan, which is an island group with a mountainous topography, the harmony with nature is the essential in the formation of structures. As a result of respect for nature, the natural order has not been intervened, the structures are shaped according to the nature.

In the Japanese house, each piece is a piece of its own. The rooms are multifunctional, capable of meeting daily needs. The adjoining chambers complement each other as if they were a whole within themselves. When necessary, sliding panels can be lifted and the spaces can be united into a single space.

In terms of scale and material usage in the residence; both spatial and structural continuity draw attention. This continuity constitutes the tatamis which are confronted everywhere in the area and the space develop depending on them. In addition, the use of dense wood in buildings is striking. Wood, bamboo, straw and paper are the main materials of traditional Japanese houses. These materials protect the building in the humid climate of Japan, allowing the house to breathe. All rooms are equipped with a modular system and high quality natural materials are preferred.

\section{References:-}

1. Ayverdi, A., 1972. “Japonya Mimarlıgı Mekânı: Özellikle İç Mekân Kuruluşuna Yaklaşım, İstanbul Teknik Üniversitesi Yayınları, İstanbul.

2. Güvenç B., 2010, “Japon Kültürü”, Boyut Yayın Grubu, İstanbul.

3. Pinto, A.F., Sheng, W.D., Hernandez, J.D., Tawinteung, N., 1997. Forest Soils and Vegetation at Ryukyu University Forest Station (Yona), Final Report, Okinawa, Japan.

4. Rasmussen, S., 1994. "Yaşanan Mimari”, Remzi Yayınevi, İstanbul.

5. Saraçoğulları, A., 2006. "Geleneksel Japon Evleri”, Yüksek Lisans Tezi, M.S.G.S.Ü. Fen Bilimleri Enstitüsü, İstanbul.

6. Sumiyoshi, T. and Matsui, G., 1990. "Wood Joints in Classical Japanese Architecture, Kajima Institute Publishing Co., May 1990, Japan.

7. Şentürer, A., 2000. “Tokyo: An Incredible Mechanism, Endless City and Modernity", Arredamento Mimarlık, Feb.2000, pp.116-129.

8. Yagi, K., 1982. "A Japanese Touch for Your Home”, Kodansha International, Tokyo \& New York.

9. Yüksek, T., 2002. "Japonya Ormanları ve Ormancılı̆̆gı”, Kafkas Üniv. Artvin Orman Fak. Dergisi, Artvin.

10. Yüksek, T., Semerci, A., Hung, P.Q., 1997. "Forest Soils Relating with Soil Type and Vegetation in Japan", Final Report, Okinawa, Japan, 1997.

11. Internet References

12. URL-1: http://www.mapsnworld.com/japan/japan-outline-map.html (Date Accessed : 12.02.2018)

13. URL-2: http://www.cografya.gen.tr/siyasi/devletler/japonya.htm (Date Accessed: 18.04.2018) 
14. URL-3: www.japonya.org/kultur/mevsim (Date Accessed: 22.05.2018)

15. URL-4: http://slices-of-life.com/2012/01/17/hanami-tradition-watching-sakura-blossoms-in-japan/ (Date Accessed : 12.06.2018)

16. URL-5: https://saimpkr.wordpress.com/2016/02/29/kobi-gelecek-vizyonu-japon-felsefesi-ve-4-sanayi-devrimi/ (Date Accessed : 08.01.2018)

17. URL-6: https://www.surdurulebilirmalzemeler.com/bambu-yapi-malzemesi (Date Accessed: 06.04.2018)

18. URL-7: http://www.completebamboo.com/species_bamboo/Phyllostachys_bambusoides.html (Date Accessed: 26.03.2018)

19. URL-8: http://factsanddetails.com/japan/cat20/sub129/item687.html (Date Accessed: 22.06.2018)

20. URL-9: https://www.asialogy.com/japon-mimarisi-geleneksel-konut-mimarisi/ (Date Accessed: 14.10.2017)

21. URL-10: https://www.jnto.go.jp/eng/indepth/cultural/experience/a.html (Date Accessed: 11.05.2018)

22. URL-11: http://afe.easia.columbia.edu/japan/japanworkbook/geography/japgeo.html (Date Accessed: 30.03.2018). 